\title{
Peran Komunikasi Interpersonal dan Proses Sosialisasi dalam Meningkatkan Partisipasi Masyarakat Kota untuk Menciptakan Budaya Gaya Hidup yang Peduli Lingkungan
}

\begin{abstract}
ABSTRAK
Kota masih menjadi pusat harapan bagi sebagian besar masyarakat yang tinggal di luar wilayah perkotaan. Kota dipandang sebagai wilayah yang mampu memenuhi harapan itu, oleh karena itu setiap tahun jumlah penduduknya semakin bertambah. Di sisi lain pe ningkatan jumlah penduduk menyebabkan penambahan beban dalam menyediakan berbagai fasilitas dan akses yang lain. Salainitu karena kebijakan pembangunan perkotaanyang kurang memperhatikan kelestarian lingkungan hidup maka akhirnya menimbulkan berbagai masalah perkotaan seperti banjir, kepadatan penduduk, lingkungan yang kumuh, kemacetan dan lainnya. Kota tidak berkembang sebagai kota yang manusiawi (humanopolis) dan nyaman secara ekologi (ecopolis). Persoalan ini dapat diatasi antara lain dengan meningkatkan partisipasi dalam menciptakan budaya gaya hidup peduli lingkungan melalui peran komunikasi interper dan proses sosialisasi. Dengan demikian perkembangan kota diharapkan menjadi kota yang berkelanjutan (sustainability).
\end{abstract}

Kata kunci : Budaya Gaya Hidup Peduli Lingkungan, Komunikasi Interpersonal, Sosialisasi, dan Partisipasi.
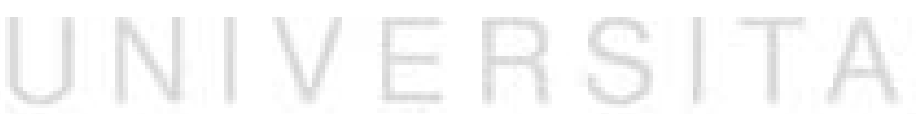

\section{PENDAHULUAN}

Membicarakan kota atau perkotaan khususnya di Indonesia memiliki daya tarik tersendiri, mengapa ? Kota terutama kotakota besar seperti Jakarta seolah memiliki kekuatan atau magnit yang luar biasa besarnya. Meskipun sebagian sudah ada yang merasa penat tetapi justru sebagian besar masyarakat daerah masih banyak yang merindukan untuk datang ke Jakarta. Mereka datang bukan untuk melihat persidangan berbagai kasus korupsi yang tidak kunjung selesai dan justru memunculkan persoalan baru, tetapi mereka ingin memperjuangkan nasib dengan mencari peluang pekerjaan yang tersisa. Fenomena ini kiranya sangat mudah 
dilihat misalnya ketika terjadi mudik Idul Fitri (Lebaran) atau Natal dan Tahun Baru.

Arus pertambahan jumlah penduduk ini pada gilirannya menimbulkan dampak pada daerah perkotaan misalnya tingkat kepadatan penduduk, akses pelayanan berbagai kebutuhan dasar seperti, bahan makanan, air bersih, transportasi dan sarana-sarana umum lainnya (Abdullah, 2009:27). Oleh karena itu ketika berbicara tentang kota atau perkotaan maka yang terbayang adalah berbagai kepadatan ruang, bangunan, manusia, barang, lalu lintas dan lain-lain demikian dikatakan oleh Eko Budihardjo dalam pengantar buku Inoguchi (2003: ix). Selanjutnya dikatakan bahwa karena kepadatan ruang dan manusia maka berkembang pemukiman kumuh dalam bentuk perkampungan kumuh legal (slum) maupun perkampungan kumuh liar (squatters). Terkesan hanya mereka inilah yang menjadi persoalan daerah perkotaan. Keberadaan kelompok miskin ini dianggap mengganggu keindahan dan kenyaman kota. Oleh karena itu tindakan yang sering diambil oleh para pengambil keputusan biasanya dengan menggusur mereka dan menggantikannya dengan bangunan-bangunan baru seperti pusat perbelanjaan (mall), perkantoran atau apartemen. Secara sosiologis keberadaan mereka tetap dibutuhkan bagi perkembangan kota yang aman, nyaman dan menyenangkan bagi masyarakat kota. Selain itu menurut Koswara dalam bukunya Irwan Abdullah (2009:30) dikatakan bahwa paling tidak ada empat persoalan dalam pembangunan perkotaan, (1) fasilitas-fasilitas lingkungan dan infrastruktur yang kurang memadahi, (2) kondisi perumahan yang kurang sehat, (3) tingginya tingkat kepadatan penduduk dan pola penggunaan tanah yang tidak teratur, dan (4) tatanan kehidupan sosial yang kurang teratur. Dengan demikian yang lebih penting adalah bagaimana menata daerah perkotaan menjadi daerah hunian yang aman, nyaman dan menyenangkan untuk berbagai aktivitas baik ekonomi, bisnis, sosial, politik dan budaya.

Menurut Eko Budihardjo (ibid) pembangunan kota-kota di Indonesia lebih tepat jika berorientasi pada pembangunan kota yang manusiawi (humanopolis), dan kota yang bersahabat dengan lingkungan (ecopolis). Pembangunan kota yang manusiawi pada dasarnya adalah pembangunan kota yang memperhatikan aspek kebutuhan sosial dan budaya masyarakat. Sebagai contoh misalnya ruang untuk saling berinteraksi diantara warga seperti tempat bermain untuk anak, ruang fasilitas sosial dan umum. Sedangkan pembangunan kota ecopolis pada dasarnya merupaka pembangunan kota yang memperhatikan aspek kelestarian lingkungan seperti tersedianya ruang hijau, kebersihan air, resapan, terjaganya kesuburan tanah dan sebagainya. Semua ini demi tercapainya pembangunan kota yang memperhatikan daya dukung alam yang berkelanjutan (sustainability). Dalam bukunya yang lain Eko Budihardjo (1993: 231) mengatakan bahwa dalam perspektif ekopolis maka lahanlahan yang terletak di daerah pantai, daerah resapan air dan kawasan lindung merupakan tempat yang harus dihindari untuk pembangunan fisik untuk mempertahankan daur hidrologi dan daur kehidupan.

Dewasa ini sering kita mendengar keluhan dari masyarakat bahwa tinggal di wilayah perkotaan sekarang ini sudah tidak nyaman lagi, gerah, kotor, macet, banjir dan masih banyak lagi kata-kata yang senada. Kondisi seperti ini ditangkap oleh para pelaku bisnis perumahan sebagai peluang baru dengan sama-sama mengangkat isu lingkungan namun dengan tindakan (action) yang berbeda. Oleh karena itu maka banyak pengembang yang menawarkan hasil produknya dengan kemasan penataan lingkungan yang nyaman melalui berbagai media. Tetapi sayangnya realitanya justru berbalik dengan apa yang ditawarkan lewat berbagai iklan itu. Proses pembangunan justru sering kurang memperhatikan faktor kelestarian lingkungan, sehingga memunculkan masalah baru, seperti banjir, kemacetan, kekumuhan baru. Seperti dikatakan oleh Takashi Inoguchi dkk. bahwa pembangunan perkotaan secara nyata merusak lingkungan alam dan wilayah-wilayah di sekitarnya (2003:2). Seperti juga dikatakan 
oleh Le Corbusier seorang arsitek dari Prancis (Eko Budihardjo, 1993: 230) bahwa “...suatu kenyataan, bahwa kota-kota besar yang ada sekarang merupakan hasil dari pembantaian terhadap alam (an assault on nature). Demikian juga Sonny Keraf (2010:1) mengatakan bahwa berbagai kasus lingkungan hidup yang sekarang terjadi baik pada tingkat global maupun nasional bersumber pada perilaku manusia yang tidak bertanggung jawab.

Bagi masyarakat perkotaan isu pelestarian lingkungan dan ketersediaan ruang untuk kebutuhan sosial dan budaya masyarakat kota menjadi sangat penting dan mendesak karena mereka yang paling banyak merasakan akibat dari kerusakan lingkungan tersebut. Dalam situasi seperti di atas maka ada satu sisi yang bisa dilakukan untuk pelestarian lingkungan yaitu mengubah gaya hidup yang tadinya kurang memperhatikan lingkungan menjadi peduli terhadap lingkungan. Oleh karena itu yang menjadi persoalan dalam tulisan ini adalah bagaimana meningkatkan partsipasi masyarakat perkotaan dalam menciptakan budaya gaya hidup peduli lingkungan ?

\section{BUDAYA GAYA HIDUP PEDULI LINGKUNGAN}

Jika diperhatikan, pembangunan wilayah perkotaan (baru) misalnya perumahan-perumahan baru, pertokoan, perkantoran dan pusat-pusat belanja (mall), kurang memperhatikan kelestarian lingkungan, misalnya kurang menyediakan ruang hijau, resapan air dan sebagainya. Yang terjadi kemudian orang merasakan kepengapan atau panas yang luar bisa pada musim kemarau dan kesusahan ketika banjir terjadi disana sini pada musim hujan tiba. Sebagai contoh mari kita coba perhatikan pembangunan berbagai komplek perumahan di sekitar tempat tinggal kita, dapat dikatakan bahwa sebagian besar sudah kurang memperhatikan faktor kelestararian lingkungan. Seperti dikatakan oleh Eko Budihardjo (Inoguchi, dkk., hal. xi) bahwa selama ini para pengusaha real estate lebih banyak membangun rumah- rumah, rumah ditambah toko (ruko), rumah ditambah kantor (rukan) dan sarana lain yang lebih menguntungkan secara finansial. Ironis sekali memang tetapi begitulah hasilnya. Sebagai gantinya mereka lebih banyak menggunakan $\mathrm{AC}$ untuk penyejuk ruangan dan mengganti pohon dengan pohon imitasi. Isu tentang pelestarian lingkungan pada dasarnya sudah menjadi pengetahuan umum kita semua baik masyarakat, pemerintah maupun pengembang. Tetapi perwujudannya masih lebih banyak pada tataran pengetahuan dalam bentuk seminar, sepanduk dan tulisan-tulisan lainnya, belum banyak menyentuh pada bentuk perilaku konkrit dalam kehidupan sehari-hari.

Selain itu mari kita coba perhatikan fenomena lain misalnya jika rata-rata setiap hari setiap keluarga menghasilkan $2 \mathrm{~kg}$ saja sampah rumah tangga, maka berapa banyak (kilo atau ton) sampah yang menjadi beban lingkungan untuk satu komplek perumahan. Kenapa menjadi beban, selama ini sebagian besar masyarakat berpandangan bahwa sampah, sekali lagi sampah maka harus dibuang, dibuang jauh dari rumah. Oleh karena itu maka biasanya setiap komplek perumahan, pasar, pertokoan memiliki armada dan petugas khusus sebagai "kolektor" dan sekaligus tenaga pembuang sampah. Pola pikir dan perilaku ini sebenarnya dapat dikatakan tidak bertanggungjawab karena sampah atau limbah yang dihasilkan dilimpahkan kepada pihak lain. Pihak lainlah yang harus menanggung efek negatifnya seperti bau busuk, kotor, pencemaran air dan sebaginya. Selain itu jika pohon-pohon sebagai media pengatur udara, penahan panas dan penyaring debu sudah banyak ditebang, jalan-jalan diaspal atau beton sehingga tidak ada kesempatan air meresap ke tanah kembali maka semakin lengkap kerusakan lingkungan di perkotaan. Kondisi ini oleh Takashi Inoguchi digambarkan sebagai akibat tidak baiknya sistem manajemen lingkungan dan gagalnya para tokoh perkotaan bekerjasama meyampaikan berbagai masalah dengan semangat persamaan dan persatuan (ibid: hal 3). Sedan- 
gkan Sonny Keraf (2010:3) menggambarkan kondisi ini sebagai akibat kesalahan manusia dalam memandang alam dan menempatkan diri dalam konteks kehidupan alam semesta. Dengan demikian maka untuk mengembalikan atau sekurang-kurangnya menjaga kerusakan alam yang lebih parah dapat dilakukan dengan mengubah cara pandang dan perilaku manusia terhadap alam. Perubahan tersebut dilakukan dengan menciptakan budaya gaya hidup peduli lingkungan. Seperti dikatakan oleh Yukio Aoshima dalam pengantar buku Kota dan Lingkungan (Inoguchi dkk., 2003: halaman xv) bahwa salah satu akar persoalan lingkungan perkotaan adalah gaya hidup.

Koentjaraningrat dalam bukunya Kebudayaan, Mentalitet dan Pembangunan (1990: 1-4) menggambarkan bahwa memahami budaya itu begitu luasnya karena menyangkut seluruh kompleks pemikiran, perasaan, perilaku dan hasil karya manusia. Selanjutnya dikatakan bahwa untuk mempermudah dalam memahami kebudayaan maka dapat dilihat dari wujudnya. Ada tiga wujud kebudayaan yaitu (1) ide-ide, gagasan, norma-norma, peraturan dan sebaginya, (2) Suatu kompleks aktivitas kelakuan berpola dari manusia dalam masyarakat, (3) Benda-benda hasil karya manusia.

Soedjatmoko dalam pengantar buku yang ditulis van Peursen berjudul Strategi Kebudayaan (1989:5), mengatakan sebagai berikut :

"usaha pembangunan dan modernisasi kita menghadapkan kita secara langsung dengan masaalah kebudayaan Indonesia ..... dan dengan proses kebudayaan kita memperbaharui diri dalam kita menjawab tantangan-tantangan kehidupan modern".

Selanjutnya dikatakan bahwa van Peursen memandang kebudayan sebagai siasat manusia menghadapi masa depan dan sebagai proses pembelajaran (learning proces) yang berlangsung terus menerus. Dalam proses ini penilaian kritis menjadi sangat penting agar manusia dapat mengabil tanggungjawab secara bebas dan dewasa atas keadaannya dan teknologi yang dipakai dan dikembangkannya. Van Peursen (ibid:) kemudian mengatakan bahwa "manusia selalu mengutik-utik lingkungan hidup alamiahnya sebagai solusi persoalan hidupnya". Dapat disimpulkan bahwa budaya dalam konteks ini dipandang sebagai strategi atau cara manusia untuk mengatasi persoalan hidupnya.

Dari penjelasan di atas dalam tulisan ini pemahaman kebudayaan ditekankan pada wujud kebudayaan yang kedua yaitu segenap perilaku berpola individu dalam masyarakat sebagai cara untuk mengatasi permasalahan hidup. Segenap perilaku yang dimaksud dalam tulisan ini adalah menciptakan atau membentuk perilaku atau gaya hidup yang peduli lingkungan. Kepedulian ini tidak berhenti pada batas kesadaran saja tetapi harus sampai pada tingkat tindakan (action) yang juga menjadi gaya hidup baru. Selanjutnya dikatakan bahwa di Jepang masyarakat peduli lingkungan ini disebut dengan "masyarakat berwawasan ekologi”. Meskipun belum banyak definisi yang digunkan dalam membahas topik ini, pengertian yang diajukan oleh Yukio Aoshami ini dapat digunakan sebagai acuan dalam memahami dan mengembangkan lebih lanjut tentang masyarakat peduli lingkungan pada masyarakat kota khususnya di Indonesia yaitu :

"Sebuah masyarakat yang peduli terhadap sinar matahari, udara, air, tanah, tumbuhtumbuhan hijau, dan karunia-karunia alam lainnya, sebuah masyarakat yang mengendalikan konsumsi sumber-sumber alam dan energi secara massal dan sebuah generasi yang tidak berguna, yang berusaha keras mendaur ulang menggunakan sumber-sumber alam secara efektif; sebuah masyarakat yang berusaha keras kembali ke alam dengan membuang sampah yang telah diolah atau didaur ulang untuk memperkecil beban lingkungan".

Secara umum tujuan masyarakat peduli lingkungan menurut Takashi Inoguchi (2003, 4) adalah :

1. Menyampaikan masalah-masalah yang secara nyata ada dan cenderung memburuk. 
2. Menjadikan kota sebagai tempat yang aman dan nyaman untuk bekerja, hidup, danmembesarkan anak-anak, tanpa merusak kemampuan generasi masa depan untuk berbuat hal yang sama.

3. Kepedulian hidup berdampingan dengan alam dalam penyelenggaraan perkotaan.

Tujuan tersebut konkritnya adalah mengurangi polusi udara dan air di perkotaan, memperkecil dan mengatur sampah rumah tangga dan industri lebih baik, mengatur sistem air seefisien dan seadil mungkin, merawat tempattempat rekreasi yang alamiah dan menyenangkan, mengembangkan sistem transportasi yang efisien dan adil bagi seluruh masyarakat dan merencanakan pembangunan perumahan yang sesuai dengan kebutuhan umat manusia dan kesinambungan ekologis di wilayah perkotaan.

Nenek moyang kita sebenarnya secara tidak langsung telah mengajarkan kepada kita untuk hidup harmonis berdampingan dengan alam. Oleh karena itu dalam tatanan kehidupan mereka diciptakan sistem budaya untuk peduli dalam melestarikan lingkungan yang diwariskan secara turun-temurun. Yang masih ada dalam ingatan penulis misalnya, tidak boleh menebang pohon "sembarangan" karena ada penunggunya, menebang pohon dengan perhitunganperhitungan tertentu, sehingga tidak setiap saat boleh menebang pohon. Selain itu tidak boleh membuang sampah di sembarang tempat karena ada yang "baurekso", tetapi harus di buang di "pawuhan", yaitu tempat sampah yang dibuat dengan menggali tanah, biasanya di belakang rumah atau disamping rumah. Membuang sampah pada "pawuhan" ini ternyata memiliki nilai pelestarian ekologis yang kompleks, misalnya berkaitan dengan aspek estetika, polusi, kesuburan tanah, dan resapan air. Uraian di atas pada dasarnya menggambarkan masyarakat yang peduli lingkungan melalui kearifan lokal dalam pelestarian lingkungan agar terjaga hubungan kehidupan yang harmonis berdampingan dengan alam yang saling menguntungkan.

Sekarang persoalannya bagaimana dengan masyarakat perkotaan yang sudah ti- dak banyak yang mengenal cerita-cerita seperti di atas dan bahkan cenderung terkena virus budaya instan yaitu beli, pakai dan buang? Meminjam istilah yang sering digunakan pada masa pemerintahan Orde Baru, "mau tidak mau, suka tidak suka" harus menciptakan budaya peduli lingkungan bagi masyarakat perkotaan. Banyak yang bisa dilakukan masyarakat perkotaan sebagai bentuk kepedulian terhadap lingkungan, misalnya dimulai dengan peduli sampah rumah tangga dan lingkungan sekitar tepat tinggal. Sebagai contoh misalnya memisahkan sampah organik dan non-organik, membuat biopori dan kompos sampah rumah tangga. Selain itu sudah mulai tumbuh berbagai aksi peduli lingkungan baik komunitas maupun individu dengan mengubah gaya hidup dengan prinsip 4R yaitu Reduce, Reproduce, Reuse dan Recicle. Namun demikian untuk menciptakan budaya gaya hidup peduli lingkungan ini tidak semudah membalikkan telapak tangan. Namun bukan berarti tidak bisa. Budaya ini dapat dimulai dari tingkat individu, keluarga, kelompok dan masyarakat. Secara individu , misalnya dapat dilakukan oleh seorang dosen dengan memberi contoh, tidak meninggalkan sampah di kelas, menyediakan tempat sampah di setiap ruang kelas. Dalam lingkup keluarga dapat dilakukan misalnya dengan memisahkan sampah basah dan kering, sampah organik dan non-organik. Selain itu menanam pohon di sekitar rumah, kalau sudah tidak ada lahan dapat digunakan dengan media pot, atau membuat lobang biopori. Demikian juga pada lingkup kelompok dan masyarakat, dapat dilakukan hal yang sama di atas. Disinilah pentingnya peran komunkasi interpersonal untuk meningkatkan partisipasi masyarakat dalam menciptakan budaya gaya hidup peduli lingkungan.

\section{PERAN KOMUNIKASI INTER- PERSONAL DAN PROSES SOSIALISASI}

Dari berbagai literatur yang membahas tentang komunikasi dapat disimpulkan bahwa pada dasarnya komunikasi adalah proses penyampaian informasi dari komunikator 
(source-sumber) kepada komunikan (recieverpenerima). Proses komunikasi itu terjadi apabila pesan yang disampaikan itu menghasilkan dampak (respon-reaksi) bagi penerimanya yang berupa tanggapan atau perilaku (feedback). Dalam konteks peningkatan partisipasi dalam menciptakan budaya gaya hidup peduli lingkungan, komunkasi interpersonal dipilih karena diharapkan dapat memiliki pengaruh langsung kepada pihak yang terlibat.

Dari berbagai sumber misalnya Hardjana, A.M., (2003), Yuyun Wirasasmita (2002), Joseph A. DeVito (2007), Richard West dan Lynn H. Turner (2006), dan Onong U. Effendi (2005), selengkapnya dapat dibaca dalam makalah penulis (Suharsono,2008), dapat disimpulkan bahwa komunikasi interpersosal pada dasarnya merupakan komunikasi yang dilakukan oleh dua orang atau lebih yang besifat langsung dan dialogis. Langsung dan dialogis yang dimaksudkan adalah bahwa segala sesuatu yang terjadi dalam proses komunikasi dapat diketahui pada saat itu juga, misalnya kalau ada yang kurang jelas maka dapat ditanyakan dan dijawab pada saat itu sehingga diharapkan dapat lebih efektif. Dengan proses komunikasi yang langsung, dialogis dan berjalan secara akrab diharapkan akan memberikan dampak yang lebih kuat pengaruhnya bagi pihak lain yang mendengar dan melihat apa yang menjadi pokok pembicaraan.

Di atas telah dijelaskan bahwa menciptakan budaya gaya hidup peduli lingkungan tidak semudah membalikkan telapak tangan, karena menyangkut perubahan baik pola pikir maupun perilaku yang selama ini jarang diperhatikan bahkan cenderung bertolak belakang dengan kebiasaan yang selama ini dilakukan oleh kebanyakan orang. Dengan konsep peduli lingkungan maka pola pikir dan perilakunya harus berubah. Singkatnya harus ada perubahan pola pikir dan perilaku baik individu, kelompok atau masyarakat harus peduli terhadap lingkungannya masing-masing. Untuk mengubah pola pikir dan perilaku tersebut dapat dilakukan dengan proses sosialisasi.
Dari berbagai literatur dapat disimpulkan bahwa sosialisasi dalam kehidupan sehari-hari berarti proses belajar untuk mengenal dan memahami bagaimana hidup bersama dengan orang lain. Dengan demikian orang tahu apa yang harus dilakukan sebagai anggota suatu masyarakat. Proses belajar ini dilakukan secara terus menerus sepanjang hidup manusia. Demikian pula dalam konteks peduli lingkungan ini, apabila dilakukan secara terus menerus dengan contoh-contoh langsung maka diharapkan dapat mempengaruhi orang lain untuk ikut peduli terhadap lingkungannya sendiri. Dengan demikian maka budaya gaya hidup peduli lingkungan akan tercipta.

\section{BAGAIMANA MENINGKATKAN PARTISIPASI MASYARAKAT ?}

Pada dasarnya keberhasilan pembangunan itu tergantung antara lain pada partisipasi semua pihak. Seperti dikatakan Eko Budihardjo bahwa dalam rangka mencapai pembangunan perkotaan berkelanjutan yang manusiawi dan ramah terhadap lingkungan antara lain tergantung pada partisipasi warga kota dan segenap stakeholders.

Secara umum partisipasi sering diartikan sebagai bentuk keterlibatan individu atau kelompok secara fisik yang meliputi tenaga, uang atau barang. Sedangkan menurut Koentjaraningrat (1982: 79), pengertian partisipasi dibagi 2 yaitu :

a. Partisipasi dalam aktivitas-aktivitas bersama dalam proyek pembangunan yang khusus (biasanya bersifat fisik-memaksa).

b. Partisipasi sebagai individu di luar aktivitas bersama dalam pembangunan (bersifat sukarela-individual).

Selama ini partisipasi lebih banyak dipahami hanya sebagai bentuk keikutsertaan masyarakat secara fisik dalam melaksanakan suatu program. Sebagai contoh ketika ada program pembanguan jalan, maka bentuk partisipasi masyarakat berupa tenaga, dana atau bentuk fisik lainnya seperti makanan dan minuman. Sedangkan menurut Norman Uphoff, partisipasi tidak sebatas keterlibatan se- 
cara fisik saja tetapi merupakan keterlibatan seseorang dalam proses pembangunan mulai dari merencanakan, melaksanakan, menikmati, memelihara dan mengevaluasi. Demikan pula dalam tuisan ini, pemahaman partisipasi berkaitan dengan kepedulian masyarakat terhadap lingkungan mengacu pada pendapat Norman Aphoff di atas. Pemahaman partisipasi seperti ini menjadi bagian dalam membudayakan masyarakat untuk peduli terhadap lingkungan. Dengan keikutsertaan mulai dari merencanakan, sampai dengan evaluasi, maka kepedulian terhadap lingkungan ini diharapkan dapat menjadi bagian hidup keseharian masyarakat, khususnya masyarakat perkotaan.

Selanjutnya bagaimana meningkatkan partisipasi masyarakat dalam menumbuhkembangkan budaya gaya hidup peduli lingkungan? Agar dapat meningkatkan partisipasi maka harus menghindarkan berbagai persoalan partisipasi masyarakat dalam pembangunan seperti yang diidentifikasi oleh Loekman Soetrisno (1995) sebagai berikut.

\section{a. Interaksi Aparat dan Masyarakat}

Selama ini ada anggapan Aparat pembangunan bahwa : (1) Proyek pembangunan yang datang dari atas (pemerintah-dinas) dianggap sebagai proyek yang sungguh-sungguh merupakan pemenuhan kebutuhan rakyat. (2) Sedangkan yang datang dari bawah (rakyat) hanya merupakan "keinginan" saja yang tidak harus diperhatikan atau dipenuhi. Sikap seperti ini menimbulkan dampak perilaku, bagi aparat pemerintah, cenderung merasa lebih tahu segalanya dan meremehkan masyarakat. Bagi masyarakat, cenderung merasa hanya sebagai obyek, tidak pernah dipedulikan dan hanya akan menerima begitu saja apa yang menjadi program pemerintah tanpa sikap kritis yang berorientasi pada kemanfaatan dan masa depan.

\section{b. Penggunaan Bahasa (yang berlebihan)}

Penggunaan bahasa, akronim dan bahasa asing yang cenderung berlebihan dalam proses pembangunan di Indonesia sering menimbulkan kebingungan bagi masyarakat dan tidak menutup kemungkinan bagi aparat pemerintah sendiri. Sebagai contoh misalnya berbagai akronim (singkatan) dan bahasa asing yang digunakan dalam berbagai bentuk kegiatan pembangunan tetapi realitanya dipertanyakan sehingga hanya "NATO" saja.

\section{c. Sikap Paternalistik}

Masyarakat Indonesia dikenal memiliki sikap paternalistik. Dalam konteks pembangunan dapat dilihat dari dua sisi yaitu (1) Aparat pemerintah atau pemimpin yang memposisikan dirinya sebagai "bapak" dan (2) Masyarakat yang memposisikan dirinya sebagai "anaknya". Dalam hubungan bapak dan anak ini maka sering kali pemimpin atau aparat pemerintah lebih bersikap seperti "bapak" dalam keluarga yang merasa wajib memberi bantuan terhadap segala permasalahan dan kebutuhan masyarakat. Mereka bertindak seperti sinterklas. Menurut Loekman Soetrisno, perilaku seperti di atas menimbulkan sikap sense of inadequacy (sikap ketidakmampuan) yang menyebabkan masyarakat kurang kreatif dan inovatif. Selain itu juga sikap dan perilaku yang kurang mandiri karena selalu meminta "petunjuk" atau "restu", bukan "bagaimana" mereka memecahkan masalahnya sendiri (alternatif-mandiri).

Menurut Koentjaraningrat (1990:69) ada segi positif dari masyarakat yang memiliki nilai berorientasi ke atas yaitu mereka akan lebih mudah diajak untuk berpartisipasi dengan memberi contoh-contoh perilaku konkrit bukan sekedar anjuran apalagi hanya perintah.

\section{d. Sikap Traumatik}

Dalam berbagai kasus masyarakat merasa tertipu oleh program-program yang dicanangkan pemerintah, sehingga mengalami berbagai kekecewaan. Sebagai contoh ketika pemerintah mencanangkan penanaman jarak untuk mengatasi krisis energi, sebagian masyarakat sudah menanam tetapi ternyata tidak ada tindak lanjutnya. Ketika pemerintah mencanangkan program penanaman sejuta kemudian semilyar pohon, tetapi realitanya dipertanyakan. Koperasi yang katanya sebagai soko guru perekonomi Indonesia, tetapi prakteknya justru sering digunakan sebgai sarana untuk menipu, maka muncul lawak 
(“dagelan”-bahasa Jawa) misalnya KUD artinya "Ketua Untung Duluan" atau "Kongkonan Utang Duit". Oleh karena itu maka harus ada usaha untuk meyakinkan masyarakat bahwa program yang dilakukan itu akan mendatangkan kemanfatan bagi semua pihak.

Selain itu menurut Koentjaraningrat (1990:74) masyarakat kita memiliki "mentalitas menarabas". Menarabas dalam berbagai aspek kehidupan, misalnya, memperoleh kekayaan, kekuasan, status sosial, ingin lulus ujian (di kampus) dengan cara yang tidak wajar dan cenderung hanya untuk kebutuhan sesaat atau jangka pendek saja. Sedangkan Irwan Abdulah (2009: 32-35) menggambarkan adanya perubahan pola konsumsi masyarakat kota (satelit) yang tidak sekedar untuk pemenuhan fisik tetapi berubah menjadi pola konsumsi simbolis yang menjadi lambang identitas dan citra (image). Gaya konsumsi seperti ini cenderung boros dan sekaligus sebagai pemisah individu dengan kelompoknya karena masing-masing berusaha mencari barang konsumsi yang membedakan satu dengan yang lain sebagai nilai tambah (value added). Selain itu sebagai dampak dari pola hidup bersaing satu dengan yang lain ini maka cenderung kurang memperhatikan lingkungan. Dalam situasi seperti ini untuk meningkatkan partisipasi masyarakat, Koentjaraningrat menawarkan beberapa konsep antara lain (1) hidup yang berorientasi ke masa depan, (2) hemat, (3) bertanggungjawab sendiri.

\section{KESIMPULAN}

Dari uraian di atas dapat disimpulkan bahwa perkembangan pembangunan daerah perkotaan sekarang ini cenderung kurang memperhatikan faktor lingkungan. Kurang tersedianya berbagai fasilitas kota seperti tempat hunian yang murah dan layak, transportasi, air bersih, listrik, pedagang informal, ruang terbuka hijau dan sebaginya. Ditambah dengan kebijakan pemerintah dalam pembangunan kota yang kurang memperhatikan aspek lingkungan sehingga kehidupan wilayah kota terlihat menjadi lebih padat penduduk dan kendaraan (macet), kumuh, panas dan kotor. Dengan kata lain kota menjadi kurang aman dan nyaman secara manusiawi dan ekologis.

Kondisi di atas dapat diatasi setidak-tidaknya terkurangai permasalahannya dengan menciptakan budaya gaya hidup peduli lingkungan. Menanamkan budaya ini dapat dilakukan denga proses sosialisasi yang terus menerus dengan perilaku konkrit melalui peran komunkasi interpersonal. Dengan komunikasi interpersonal ini diharapkan masing-masing individu dapat berbagi informasi secara langsung sehingga lebih mudah dalam proses perubahan perilaku. Selanjutnya dengan proses sosialisasi dan komunikasi interpersonal ini diharapkan dapat meningkatkan partisipasi masyarakat perkotaan untuk peduli terhadap lingkungan.

Meskipun tidak semudah membalikkan telapak tangan dalam menciptakan budaya gaya hidup peduli lingkungan, namun dapat dilakukan mulai dari diri sendiri, kelompok dan masyarakat dengan tindakan yang paling sederhana di sekitar kita.

\section{DAFTAR PUSTAKA}

A. Sonny Keraf, Etika Lingkungan Hidup, Penerbit Kompas, Jakarta, 2010

C.A. van Peursen, Strategi Kebudayaan, Kanisius, Yogyakarta, 1989.

Eko Budihardjo dan Sudanti Hardjohubo jo, Kota Berwawasan Lingkun gan, Penerbit Alumni, Bandung, 1993.

Irwan Abdullah, Konstruksi dan Reproduksi Kebudayaan, Pustaka Pelajar, Yogyakarta, 2009.

Iwan J. Azis, dkk., (editor), Pembangunan

Berkelanjutan, peran dan kon tribusi Emil Salim, Gramedia, Jakarta, 2010

Koentjaraningrat, Kebudayaan, Mentalitas dan Pembangunan, Gramedia, Jakarta, 1990.

Loekman Soetrisno, Menuju Masyarakat Parti sipatif, Kanisius, Yogyakarta, 1995.

Suharsono, Komunikasi Interpersonal dan Ke berhasilan Kepemimpinan, Jurnal Ilmu Komunikasi, UBM, Desember 2008. Takashi Inoguchi, dkk. (editor), Kota dan Ling kungan, Pendekatan Baru Masyarakat Berwawasan Ekologi, LP3ES, Jakarta, 2003. 
1. Artikel berupa hasil penelitian, baik penelitian lapangan maupun kajian pustaka atau yang setara dengan hasil penelitian, serta kajian konseptual di bidang komunikasi

2. Bisa juga memuat hasil penelitian/skripsi dari mahasiswa yang sudah dinyatakan lulus tetapi dalam penulisannya didampingi oleh pembimbingnya dan disesuaikan dengan format yang ditentukan

3. Artikel ditulis dengan bahasa Indonesia atau bahasa Inggris. Bila artikel menggunakan bahasa Indonesia abstraknya menggunakan bahasa Inggris, sedangkan bila artikel menggunakan bahasa Inggris, abstraknya berbahasa Indonesia

4. Abstrak ditulis sebanyak 100-150 kata, ditulis dengan huruf miring serta dilengkapi dengan kata-kata kunci. Bila artikel yang ditulis merupakan hasil penelitian maka abstrak harus memuat latarbelakang,dan perumusan masalah,tujuan,metode,hasil atau kesimpulan penelitian

5. Panjang naskah sekitar 18-22 (maksimal) halaman Quarto, di luar bagan,gambar/foto dan referensi

6. Pengetikan naskah menggunakan program Microsoft Word, spasi ganda (Spasi 2), jenis huruf Times News Roman, ukuran 12. Marjin kanan-kiri, atas bawah $3 \mathrm{~cm}$.

7. Setiap naskah diserahkan dalam bentuk 1 print out (hard copy) dan 1 soft copy yang dikirimkan via e-mail atau dikemas dalam CD dengan format rtf atau Doc

8. Komposisi artikel hasil penelitian : (1) Judul, (2) Nama Penulis (tanpa gelar), di bawah nama penulis dicantumkan afiliasi/alumni, (3) abstrak, (4) kata kunci, (5) Pendahuluan (tanpa sub judul), (6) Tinjauan Pustaka/Kerangka Teori, (7) Metodologi Penelitian, (8) Hasil dan Pembahasan (9) Simpulan dan Saran, (10) Daftar Pustaka (hanya memuat kepustakaan yang dirujuk dalam artikel

9. Komposisi artikel konseptual: (1) Judul, (2) Nama Penulis (tanpa gelar), (3) abstrak, (4) Kata kunci, (5) Pendahuluan (tanpa sub judul), (6) Sub judul- sub judul sesuai kebutuhan, (7) Penutup, (8) Daftar Pustaka (hanya memuat kepustakaan yang dirujuk dalam artikel).

10. Penulisan kutipan dibuat dengan catatan perut yang memuat nama belakang pengarang,tahun penulisan, dan halaman penulisan.

Contoh:

Satu penulis

Dua penulis

:..............(McQuail,1994:43)

Lebih dari dua penulis

..................(Green dan Vivian,2005:56)

11. Penulisan daftar pustaka menggunakan model: Nama Belakang, nama depan.Tahun Penerbitan, Judul Buku (cetak miring).Kota:penerbit.

Contoh:

Conboy,Martin.2003.The Press and Popular Culture.London:Sage Publication.

12. Print Out dan soft copy artikel ( dalam format RTF/doc) bisa dikirimkan paling lambat satu bulan sebelum periode penerbitan kepada :

\section{PUSKA (PUSAT KAJIAN KOMUNIKASI) PROGRAM STUDI ILMU KOMUNIKASI} UNIVERSITAS MULTIMEDIA NUSANTARA (UMN)

Jalan Boulevard Gading Serpong Tangerang Banten

Telp + 622154220808

Fax +6221 54220800 .

Atau bisa dikirimkan via email ke: Ketua Penyunting Jurnal Komunikasi,

Indiwan seto di alamat email: indiwan_seto@yahoo.co.id 